\title{
Awareness of Farm Women in Regards To Agricultural Coverage in Media
}

\author{
Gursimar Kaur Middha, Amrinder Singh,
}

\begin{abstract}
In most developing countries, like India, women are responsible for nutrition and food security at household level and even at agricultural level whereas they are not considered 'farmers'. They just do this duty as being addressed as housewives. Whereas, women are more than that.The 2020 prediction says that more than half of new Internet users in India will be from rural societies, and rural users will constitute almost half (48\%) of connected users (The Rising Connected Consumer in Rural India: by The Boston Consulting Group suggests). Also, number of Indian rural internet users will reach to 315 million users in 2020. The growth will be driven by cheaper handsets, explosion of wireless and wireline networks. Even various studies after 201 suggested that Facebook, WhatsApp and YouTube are now being used to share diverse farming based information across different parts of India. Similarly, the contribution of females, in modern times, is unlimited both at home and farm. Women have an understanding of the latest technologies which could be amalgamated with agriculture. For Agriculture, media aims at encouraging national integration, dissemination of message, educating women, providing healthy entertainment and spreading of essential knowledge to fuel agricultural production.Punjab is a land of farming and known as 'Bread Basket' and its women are equally contributing in the agriculture. In the various villages of Punjab, women are oriented to farming and use Media for agricultural tips, agricultural know-hows, recipes, sessions based on agriculture, etc. Even a wide range of mass media including newspaper, magazines, books, radio, television etc. are being utilised by farm women based in Punjab. The following study will focus on the utilisation of Media, in various forms, by farm women of Village Pakhowal, Punjab for analysing agricultural coverage.
\end{abstract}

Keywords- Media, Awareness, Farm Women, Agricultural Coverage.

\section{INTRODUCTION}

Punjab (the five rivers region) is amongst one of the supremely productive areas on the earth. The area is epitome for growing wheat crop. Also, rice, sugarcane, vegetables and fruits are also a part of grown products. In India, Punjab is called the "Granary of India" or "India's bread-basket." Many records incorrectly remark that it produces $43 \%$ of India's wheat, but that is actually its involvement in contribution to the national pool. Punjab harvests $17 \%$ of India's wheat production, and $11 \%$ of India's rice production.As per the prevailing scenario in Punjab, maximum of the population is residing in rural areas where the individuals have agriculture based occupations or work related to agriculturesuch as dairy or animal farming as their major source of income. Punjab is known as the bread basket of India which supplies food grains to the whole nation The total of population based in rural areas of Punjab is over 1.73 crore, out of which $62.5 \%$ belonged to rural population. (2011 census).

Revised Manuscript Received on November 15, 2019

Gursimar Kaur Middha, Department of Media CT University Ludhiana, India simarmiddha.1288@gmail.com

DrAmrinder Singh, School of Management Studies CT University Ludhiana, India amrinder.17046@ ctuniversity.in
Inover-all, the Punjab's area is just $1.4 \%$ of entire area of India, but it harvests around 12\% of the cereals production of the country. Wheat is the largest grown crop. Among other significant crops are cotton, rice, sugarcane, maize, barley and fruits. Barley, wheat, rice, maize and sugarcane are primary crops grownin the land of Punjab. Bajra and jowar are amongst chief fodder crops. In the fruits category, it harvestsplentiful kinnow stock.Canals and tube wells are chief sources of irrigation in Punjab. The harvest of rabi or the spring comprises of wheat, gram, barley, potatoes and winter vegetables. The harvest of Kharif or the autumn comprises of rice, maize, sugarcane, cotton and pulses. Chief contributor to the gross state domestic product (GSDP) of Punjab is Agricultural sector. According to 201314 statistics, the agriculture and allied industries' contribution in GSDP at factor cost is $28.13 \%$.

\section{Importance of Women in Agriculture}

- Women are deliberated as constructors of a nation's advancement and shaping future.

- They ought to play a significant role in the economy of a state as well.

- Women are the strength of rural society.

- Mostly, women achieve different kinds of work for the existence and agriculture is considered as the major unorganized sector in which a lot of rural women actively take part.

Women, Agriculture and Media

Agriculture is a broad term to describe all parts of food and natural resources. It contains animals (livestock and pets), food and nutrition, farms, and the atmosphere. Many media organizations specially look for media recruits to report agricultural topics.

For rural areas, transistor, TV, newspapers and magazines play a dynamic role in diffusion of information, displaying advertising, educating, enlightening and clarifying people, solidification of national incorporation, and generating national individuality. Mass media shapes thoughtfulness, approaches, viewpoint and behavior because of their spread, mass media is way more influential and its influence is also better as compared to that of other media forms (Saxena).

There are twofold chief usage outlines for mass media. The first and foremost ritualised usage deals with its characteristic use for deviation or for intake of time for fitness, education, and political materialcollected by folks through submissive acquaintance to mass media. The contributory usage is purposive or useful for informational reasons, through seeking media content.

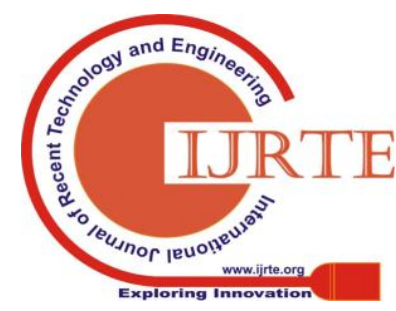




\section{Awareness of Farm Women in Regards To Agricultural Coverage in Media}

Agriculture cannot develop without exploring all possible networks of information based on agriculture because such information is best circulated by various types of channels. Media in various forms especially newspapers, should be used to reserve information for future reference. Growth and transfer of agricultural technology is significant.

The mass media has the prospective for providingevidence, encouragement, and training for women in rural areas. Rural women also need material based on the prominence of worthy source of in taking clean water and the avoiding of common diseases spreading in the areas. Deaths and undernourishment of children are chieflypredominant in rural communities; consequently, a lot of information on child care is compulsory. Rural inhabitants also necessitatematerial on social contribution in any platform for rural progress.

The programmes broadcasted on mass mediamust now emphasis on the apt quality and category of education which the women based in rural partsget. The type of education regulates what rural women gain and consequently, they would feature in the growth of a nation in whatever area and at any level. Education must also be provided to the whole population on the requirement to possess most of the mass media such as radio, television, newspapers, etc, as well as on applying it to get to know about some of the programmes they air and the correct broadcast time. Also, all stations of Media, chiefly radio stations are giving signals to rural areas should be educatedon the way of exploring the cultures of these areas. Therefore, the native language of such areas must be utilized. Women are the backbone of not only a home but also the world's growth panel. As now women are stepping out after making their homes perfect, they are using the media for personal and professional use. Women and media are now going hand in hand. From teaching their kids to ruling the corporate world, women are using it effectively. Not just urban but even rural women are using media. Rural women signify the unseen workforces in a scope of actionsstretching frompreparation of land till the harvesting of the agricultural produced. The mass media consumption behavior of farmwomen is vital to lead the latest progresses in technology of farming and for improving their technical skills which ultimatelyresult to their improved production in their farms and households. Sometimes, due to discrimination among males and females, the latter are being overlooked in some arenas. Now the time is when women must be authorized by improving their skills, know how's,informationand their hold to IT (Information technology) also. This will strengthen their ability to develop more and walk along men equally. Commencing from the schoolroom to the farms to the conferencing halls, women in agriculture sector are serving to make the way for an enhanced upcoming times. As front-runners, it is our duty to make unquestionable that the coming generation of females are literate, empowered and encouraged to take on the tests of matching up to the world's growing needs of foods, fiber and fuel. Although women and their role in agriculture are indispensable, they are not given their due. Usage of media by them is important but the gap between women and technology is huge. To study their usage of media related to agriculture was the main focus of this study.

Objectives of the Study
1. To mark the use of media by farm women in village Pakhowal.

2. To evaluate the awareness of farm women regarding agricultural coverage.

\section{REVIEW OF LITERATURE}

Sharma (2012) in her study on "Mass Media utilization pattern of farm Women" stated that on the basis of the results which were obtained from this study, that most of the respondents belonged to younger age group, illiterate people who were having marginal holding of land and they had no participation in any social organization. Most of them were owning ratio sets $(60 \%)$ andonly $30 \%$ of themhad television andthen newspaper was subscribed by only $25 \%$ of the respondents. Regarding the utilization pattern of the mass media, $50 \%$ of the respondents were categorized among the medium utilizers and on an average $20 \%$ of them were among the major utilizers of all mass media. Entertainment programmes were categorizedhighest as preferred by the most of the respondents. The chieflimitations in using mass media was lack of free time, followed by use of some words and languages which were technical. Kakade and Kolar (2013) through the study "Media Habits among Women Organic Farmers in Karnataka" determined that the main purpose of media is to update, teach and encourage the community to accept new ideas and technologies so as to improve their living conditions. The reading habit of women who are well educated,based in rural areas, are high due to increased level of literacy. He studies that only a least number of women did not read newspapers and magazines. The only purpose for reading the two was for getting information and the other was for entertainment. Nearly one third of the women were radio listeners and $99.18 \%$ of them watch television each day where, among them, majority of women were spending more than three hours per day. Mobile phones and televisionwas amongst most of the frequently used media among women as compare to other forms of media. This study also specifies that internet was not used by more than half of the respondents the reason was lack of internet facility and technical illiteracy among them. It can be therefore concludedthat television and mobiles are the most commonly used media among women for the purpose of communication and education. Islam et al (2014) through the study 'Rural Women's Awareness on Agricultural Extension Services: a case study on Manikgonj district in Bangladesh" concluded thatthediscovery, interestingly, reveals that almost all the rural women in the study possess at least medium level of awareness on agricultural extension activities of various public sector extension organizations, particularly the DAE, the conventional agricultural extension agency of the country. Besides, rural women's awareness on extension activities displayednoteworthy positive associations with their education, extension media contact and cosmopolitans, while a negative association was established with their family size. This certainly implies that the first three factors might be instrumental for the accomplishment of any gender sensitive extension program. 
Lekshmi and Balasubramani (2014) through study on "Mass media utilization behaviour of farm women" determined that radio was the most widespread media used by the farmwomen probably due to its less cost, easy accessibility and portability. However, skill based knowhows involving audio and visual effects authorization the wide scale use of media like TV. Community television sets can be installed in public places such as markets and community halls for smoothing easy viewing by farmwomen. Though $60 \%$ of the farmwomen in the study area had prime level of education, the usage of farm periodicals was only by $10 \%$ of the sample, however this $10 \%$ were regular subscribers to farm periodicals. The Agricultural Universities and KrishiVigyanKendras can encourage the use of this media efficiently by making accessible these publications free of cost to the farm women; who are members of local media aids. Likewise the feedback behavior of farmwomen can be improved by giving interesting agricultural programmers for women through television such as courtyard farming, new farmingequipment and reducing the labor of farmwomen and similarly by increasing the coverage of agricultural features in newspapers. Farmwomen have been long bestowed as invisible workers in agricultural scenerio, and their involvement for agricultural development is remarkable. Hence establishing and endorsing effective use of media forums in radio, print media and television would play an important role in informing farmwomen for agricultural growth.

Shamsodani and Shojaee (2015) scrutinized the factors affecting the lifestyle of rural women in Mamasani region, Iran. Methods such as music, books, movies and clothing consumption, ways of relaxation, and food habits were used to hypothesize a lifestyle index. The chief hypothesis werethose factors such as gender norms, belief, media advancement, age, education and socio-economic status encourage the lifestyle of the analyzed women. The research method was vivid, based on cluster-sampling method, and the study population comprised all women from 15 to 65 years old who are residing in Fahimiyan village in Fars province. Among those, 390 subjects were nominated based on Cochran formula. The results presented that the most important factors that affect women's lifestyle are gender norms, age and beliefs.

\section{MATERIALS AND METHODS}

The present research, 'Awareness of Farm women in regards to Agricultural Coverage in Media' was carried out to get an idea about the awareness of farm women based in Pakhowal village of Punjab regarding agricultural coverage in different media and their interest in same.To undertake this study a systematic research methodology was designed. A quantitative method was used forgathering of data and succeedinganalysiswere

made using the primary data gathered. In the present study, the questionnaire was designed and distributed among the farm women of village Pakhowal, in order to get desired results.

A survey research design was adopted. A list of households who had main occupation of agriculture was made with the help of village sarpanch. A total of 100 female respondents were selected by lottery method. A structured questionnaire was the main research tool for data collection. The questionnaire contained 24 questions including both open ended and close ended questions where the farmwomen had a choice to choose more than one options in some particular questions.

\section{RESULTS AND ANALYSIS}

The present study focuses on the awareness of farm women regarding agricultural coverage in different media like newspapers, books, magazines, radio, internet and television. After the data was collected by filling of the questionnaires containing 24 questions by 100 farmwomen of village Pakhowal the results were gathered. This chapter presents the results obtained from the analysis of the collected sample which were in the form of a survey.

Table 1: Distribution of respondents according to age

\begin{tabular}{|c|c|}
\hline $\begin{array}{c}\text { Age } \\
\text { Group } \\
\text { (Years) }\end{array}$ & $\begin{array}{c}\text { Number of } \\
\text { Respondents }\end{array}$ \\
\hline $25-35$ & 37 \\
\hline $36-45$ & 33 \\
\hline $46-55$ & 30 \\
\hline Total & $\mathbf{1 0 0}$ \\
\hline
\end{tabular}

4.1 Media outreach in Village Pakhowal

In this study, Print Media, Radio, Social Media and Television were preferred as source of information.Under Print Media, usage of newspaper was studied along that, usage of Books, Magazines and Punjab Agricultural University magazines were asked from the respondents. In the Social Media context, usage of Twitter, Facebook, Whatsapp and Agricultural Websites was studied. Moreover, for usage of Radio and Television for getting agricultural news was taken under consideration. These media were used by farm women and the usage would be discussed one by one in upcoming data. 


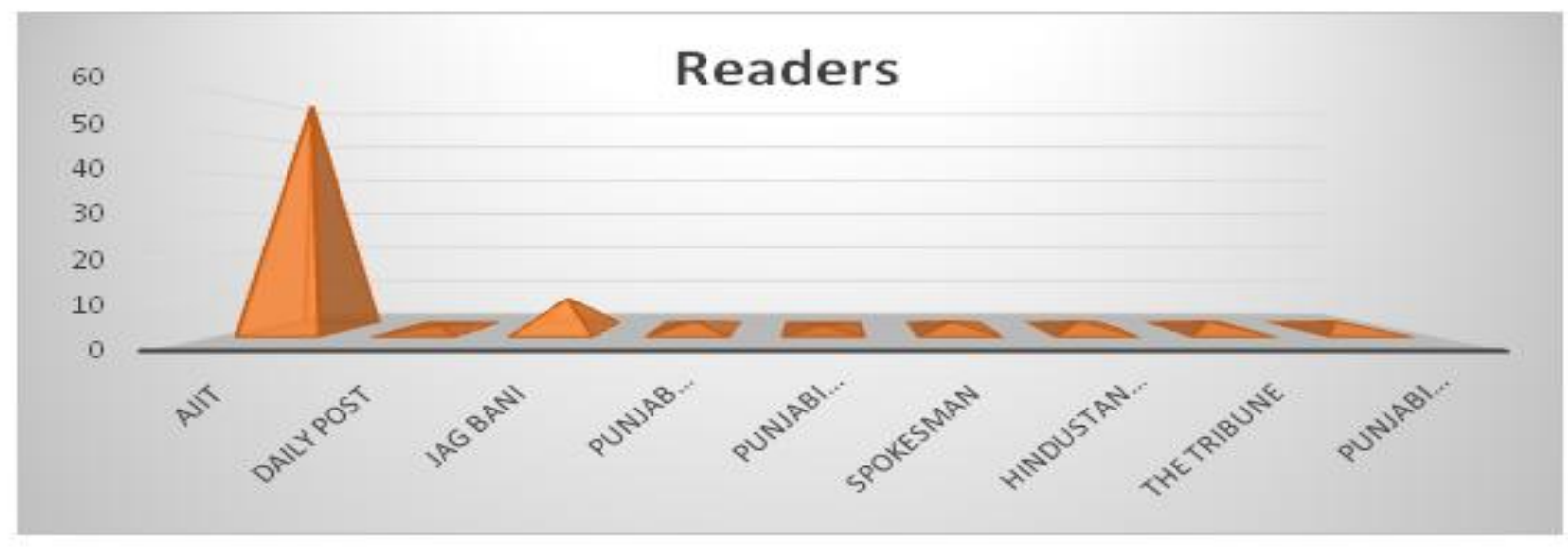

Fig. 1: The most preferred newspapers ifvillage Pakhowal

\subsection{Preferred Newspapers}

During the study, it was noted that $\mathrm{mc}$ ferred newspaper in the village household were Ajit, (58\%) then, Jag Bani $(8 \%)$ and others newspapers like Punjabi Tribune, Daily Post, Spokesman, Punjab Kesari, Hindustan Times and The Tribune are read only by $1-2 \%$ people.

Table 2: Newspaper reading status in village Pakhowal

\begin{tabular}{|c|c|}
\hline Name of Newspaper & People reading \\
\hline Ajit & 58 \\
\hline Jag Bani & 8 \\
\hline Daily Post & 1 \\
\hline Punjab Kesri & 2 \\
\hline Spokesman & 2 \\
\hline Hindustan Times & 2 \\
\hline Tribune & 2 \\
\hline Punjabi Tribune & 2 \\
\hline Punjabi Jagran & 1 \\
\hline
\end{tabular}

Ajit has always been a preferable source of news especially in villages of Punjab. Being a vernacular paper, this newspaper is essential for many households. Then the reading amount for Jag Bani shows that yet again vernacular paper is given importance.In Punjab's villages, vernacular newspapers have always been the best source of information based on every topic.

\subsection{Television viewing pattern of Farmwomen}

Every women watches television but not necessarily agricultural coverage. They watch TV for entertainment purposes the most and not specifically for agricultural coverage. Whereas, stating the reason of lack of time, farm women watches television for a few hours that too not on regular basis. The time for watching Television is not specified and whenever they are free, they watch. The other family members, especially children in the families, watch television for long hours and for different purposes.

In village areas, the most preferred TV connection is DD Direct DTH $(51 \%)$ as it is connected for free in village households by Punjab Government.
Apart from this, Fastway Cable (45\%) is chosen in Pakhowal Village. Rest of the households have Tata Sky $(2 \%)$ and Airtel and Videocon (1\%).

Farmwomen watch TV on regular basis but not necessarily for agricultural information or news related to that. The time for watching television is not fixed. The reason stated was that they do not get time to watch TV for long hours.

A woman aged 55 stated that, "I hardly get time to watch Television but I prefer to watch some daily soaps regularly. Even sometimes my husband switches to news channels or agricultural information but then I do not focus on that. I prefer watching daily soaps for relaxation."

\section{Number of Households}

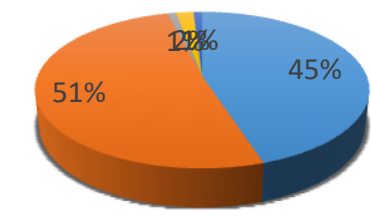

$$
\begin{aligned}
& \text { Fastway } \\
& \text { Airtel DD Direct DTH } \\
& \text { घideocon }
\end{aligned}
$$

Fig. 2: Showing cable connection of the village Pakhowal

\subsection{Radio Listening Farmwomen}

Farmwomen are truly dedicated to their work and only $30 \%$ of women listens to Radio but that too necessarily for agricultural programs. $70 \%$ women are not regular radio listeners rather prefer Television over Radio for any type of news or information.

A woman from village Pakhowal, age 35 stated that, "We have a radio set which is ancestral but that is just for memory. We hardly use it. We have switched to televisions for our entertainment."

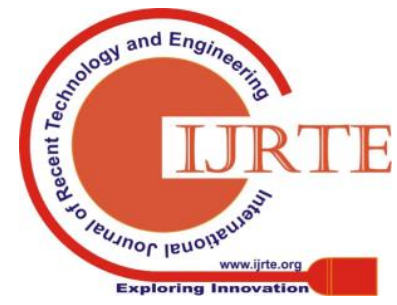




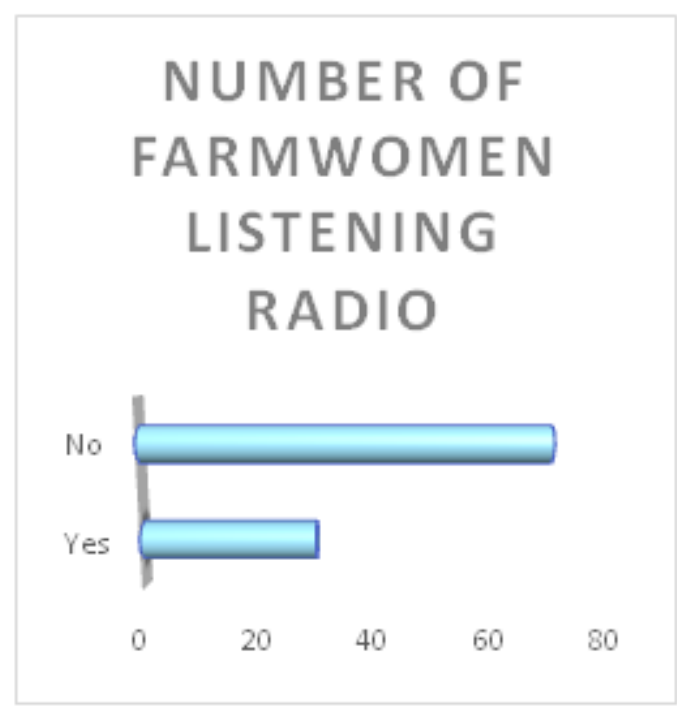

Fig. 3: Data of Radio listening Farmwomen

4.5 Use of Books, Magazines and Punjab Agricultural University Journals

Out of $23 \%$ of women, the study noted that only $19 \%$ are readers of Journals distributed by Punjab Agricultural University and just $4 \%$ women read books for agricultural information and no one has subscribed to any specials magazines for agriculture.

Keeping in mind the usage of especially books, magazines and PAU journals, during the interview a candid reply was taken from a 40 years old woman who said, "We have supply of PAU journals but I hardly read it. My husband is a frequent and regular reader. Apart from PAU journals we do not have any other book or magazine related to agricultural news."

Table 3: Wifi Availability in Households

\begin{tabular}{|c|c|}
\hline Response & Number \\
\hline Yes & $\mathbf{5 8}$ \\
\hline No & $\mathbf{4 2}$ \\
\hline Total & $\mathbf{1 0 0}$ \\
\hline
\end{tabular}

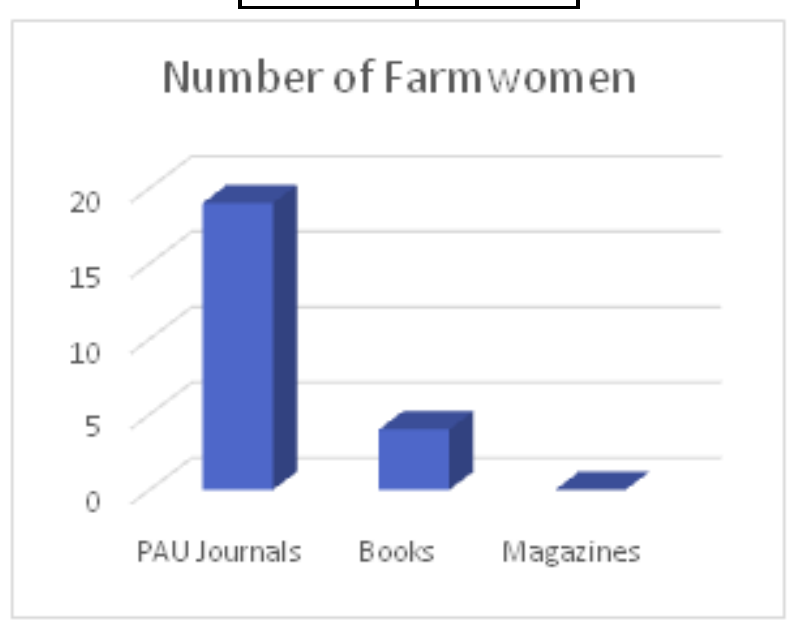

Table 3 shows the every village at the present scenario is equipped with Wifi facilities. Some villages still lack in the availability of Internet services. The data shows that 58 households of the respondents have the internet facility where as $42 \%$ of the respondents do not have the Internet facility.

\subsection{Access to Internet}

Internet is a very influential method that has changed the path of gaining information and communication. Educational places, workplaces and households are under internet usage.

Exposure of Internet was witnessed as a common phenomenon but on the parallel side, women with no exposure of internet are also not less.

Table 4: Farm Women: Accessing Internet

\begin{tabular}{|c|c|}
\hline Response & Number \\
\hline Yes & 51 \\
\hline No & 49 \\
\hline Total & $\mathbf{1 0 0}$ \\
\hline
\end{tabular}

Table 4 shows the rankings for the accessibility of internet with farm women on different devices. The results came out as $(51 \%)$ users have the internet facility and (49\%) do not have the access to internet.

A woman of 55 years stated that, "I do not know what exactly is internet. Certainly, my children and grandchildren are using these things but I do not understand a bit. Even my eye sight and my age do not let me use internet. I am completely comfortable with what was taught by my ancestral for agricultural awareness. I do not need any help."

\subsection{Use of social networking sites}

Social networking sites makes possible to interact with the people next door or across the world with one click. This allows the people to keep in touch with their friends and family that may live far away. Whoever they may need, whenever they may need you, they are able to reach them via social networking sites. These sites are very beneficial in keeping the usage in touch with virtually the entire world. 


\section{Awareness of Farm Women in Regards To Agricultural Coverage in Media}

Table 5: Farm Women: Use of Social Networking sites

\begin{tabular}{|c|c|}
\hline Social Networking & Number \\
\hline Facebook & 18 \\
\hline WhatsApp & 50 \\
\hline News Apps & 18 \\
\hline Twitter & 4 \\
\hline Agricultural Websites & 11 \\
\hline
\end{tabular}

Table 5 shows the usage of social networking sites for different purposes. Farm women of different age group have their own choice of selection from the available networking sites, websites and apps. In the above data it is clear that significant number $(50 \%)$ maximum number of the women are using Whatsapp as social networking. Facebook and News Apps show a same number of usage by Farmwomen i.e. 18\%. Other than this, $11 \%$ of Farm Women are aware of Agricultural Websites and use them. Twitter, at its least count, is used by only $4 \%$ of farm women.

\subsection{Use of News Apps in mobile phones}

Smart phones have taken over in past years. The phones support all type of media with the internet requirement and works on $3 \mathrm{~g}$ and latest $4 \mathrm{~g}$ network. The news apps are available and all types of news is inside a small device which connects one with world. There are categories of news as well for example Entertainment, Politics, Social, Business, Environment, Life and Style, Agriculture, etc. Farm women also have news apps in their mobile phones to catch hold of agricultural coverage worldwide but this number is least with only $18 \%$.

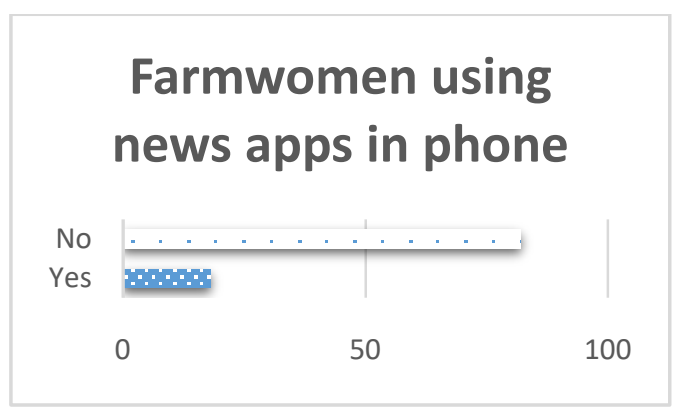

Fig 5: Use of News Apps in mobile phones

\subsection{Use of Television by Farmwomen}

Television is the friendliest source of entertainment and knowledge for farm women. They plug in Television the most as compared to usage of mobile phones or reading newspaper and not even listening to radio. The connection mostly used is DTH wish is supplied for free by Punjab's government and only taking installation price that too only for first time. The time for watching television is not specified of Farm Women. For this reason, $72 \%$ farm women watch agricultural related programs on television.

Table 6: Farmwomen: Preferred Agricultural Coverage Source

\begin{tabular}{|c|c|}
\hline Source & Number \\
\hline Radio & 0 \\
\hline Television & 90 \\
\hline Newspaper & 10 \\
\hline Internet & 0 \\
\hline
\end{tabular}

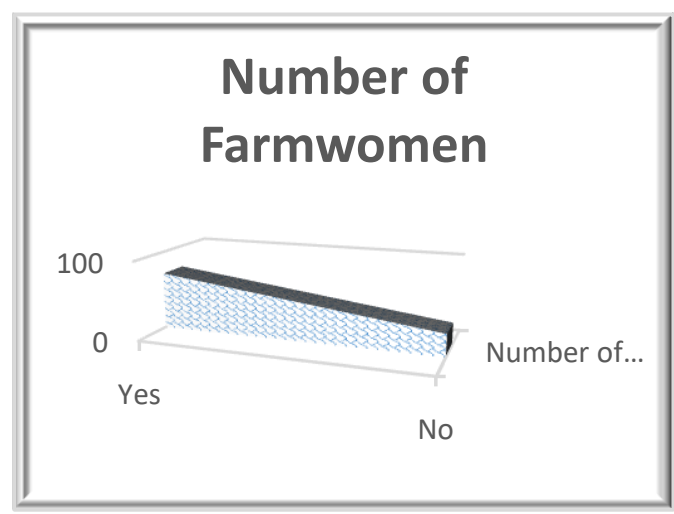

Fig. 6: Number of women watching Agricultural Related Programs

Table 6 reveals the ranking of preferred sources of agricultural coverage preferences among farmwomen. An overwhelming number of women preferred television to get the latest agricultural updates (90\%) followed by newspapers $(10 \%)$. It is shocking that no one now prefers radio or internet for getting news or any other update regarding agricultural sector. Television is now available in every household so it may be the reason that television is most popular among other devices for getting the updates. Newspaper is less but not completely forgotten. The reason Farm Women stated that they do not have time to read newspapers, listen to radio and use mobile phones.

\subsection{Interest in media}

As a normal woman holds her duty at home first, Farm women of Punjab are also under the same notion. Giving priority to household and farm chores, farm women based in Pakhowal lacks interest in Media. 
Their households may have television, radio and newspapers but farm women have no interest to keep up with agricultural coverage in different media. Only a few women were interested in reading agricultural part in newspapers, watching agriculture related programs or listening to radio for agricultural news or information.

\subsection{Newspaper reading habit of Farm Women}

As the study was limited to Farm Women, most of the women stated that they do not read newspapers at all, as they are busy and occupied with household work. Only $19 \%$ women read newspaper as compared to $81 \%$ of women who do not read newspapers at all. Although, $71 \%$ of household in the villages have subscribed to newspapers but the regular readers are male members of the family.

Table 7: Farmwomen who have interest in agricultural coverage

\begin{tabular}{|c|c|}
\hline Response & Number \\
\hline No & 91 \\
\hline Yes & 9 \\
\hline Total & 100 \\
\hline
\end{tabular}

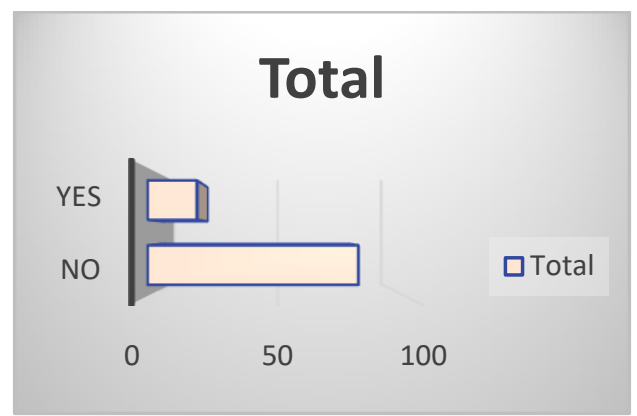

Fig. 7: Showing the Farmwomen reading newspapers

This clearly shows that number of farm women $(91 \%)$ are not interested in knowing agricultural coverage in different media as compared to only $9 \%$ who are interested in agricultural coverage.

Apart from this, none of the women clipped any information i.e. cut out clippings from magazines or newspapers for future use. Also, there was no specific news/information searches made through media which were based on agriculture. There were also no women who implemented any information found on media, related to agriculture in their daily lives. Finally, it was found that no women considered Media as their help in agricultural work.Television was the favorite source of getting any type of news.

\section{Reading scenario in the family}

Favourable reading environment in the family may act as a promoter of reading habits among farm women.

Whereas, all the women and even farm women give priority to household responsibilities so they hardly put in efforts to read newspapers. Rather, men of the houses read the most. They prefer reading vernacular newspapers. Also, farm women least give the time to read books or magazines based on agricultural coverage.

\section{FINDINGS}

The data collected were exposed to statistical analysis for noteworthy fetching of the results. The data were scrutinized by using simple statistical tools like frequencies, percentages, etc.

Demographic profile stated that the most of the sampled farmwomen belonged to relatively the younger group i.e. $25-35$ years of age $(7 \%)$. $98 \%$ of the total farmwomen were married and 2 of them were widowed. Most of the farm women were duly working as home makers and then as workers on their farms. Status of family revealed that most of the farmwomen were living in nuclear family $(79 \%)$ whereas farmwomen living in joint family were $21 \%$. Educational qualification of most of the farm women $(53 \%)$ was up to matric level, till senior secondary was only $20 \%$ as most of them did not continue studying and left out after $10^{\text {th }}$ standard. Moreover, $16 \%$ of them were Graduated and mostly in Arts stream. Apart from this, $10 \%$ of farm women were uneducated and only $1 \%$ did her masters.

The nature of approachability of media revealed that about $71 \%$ of the total rural households had subscribed to everyday newspapers. The results revealed that vernacular languages were most favored language by the households. In this framework, all the $71 \%$ of the total readers conveyed that they are satisfied reading newspapers in their mother tongue language i.e. Punjabi. Among Punjabi newspapers, Ajit (58\%) and Jagbani (8\%) were widely chosen and accepted newspapers by the rural households for reading. It is clear from the observation that households have subscribed to daily newspapers but the regular readers are men of the household. $81 \%$ of the farm women do not read newspapers at all even though they have daily newspaper supplied at their home.

Television exposure of farmwomen was $100 \%$. They watched television on firm and daily basis but not basically for agricultural information or news related to that. The time for watching television is not fixed. The reason specified was that they do not get time to watch TV for long hours. Another form of media was analysed in the study i.e. Radio. There were only $30 \%$ of Radio users whereas $70 \%$ of women did not use Radio sets for any kind of purpose. In urban areas, radio sets moved to mobile phones and in car's stereo system and similar is the scenario with rural areas. In some of the households, radiosetswere just kept as a memory and for decoration purposes. Currently, people choose to plug in headphones and listen to radio on phones. 


\section{Awareness of Farm Women in Regards To Agricultural Coverage in Media}

The other aspect considered was usage of books, magazines and journals by Punjab Agricultural University. Farmwomen were aware of PAU journals rather than about books or magazines based on agricultural coverage. Households had supply of PAU journals but as in case of newspapers, this was same that mostly men of the houses read the journals. Books and Magazines did not have any importance in rural households. Then comes the usage of internet. Farmwomen did prefer internet for appealing news and agricultural information but yet again they did not use internet as the eventualsource of getting awareness. $51 \%$ of women had access to internet whereas $49 \%$ of the women did not use internet facilities. The favored sources were the smart phones rather than using laptops or computers. Internet is used nowadays mostly for social networking sites like facebook, twitter, whatsapp, agricultural websites, etc. The most liked social app is Whatsapp (50\%) which

farmwomen are making use of. They share through it every type of messages, videos and gifs. This sharing was not just limited to agricultural news or any other farm related information. Whatsapp's calling feature was most loved thing by farmwomen, they felt easy and cheap to talk over with relatives all around the world. Then, Facebook marked its position with $18 \%$ of usage by farmwomen, most of the women had their account on Facebook but there were women who used Facebook just through their child's phone. Apart from this, apps related to agriculture were used for just $11 \%$ and twitter being the slightest one is just for $4 \%$. Keeping oneself updated and well informed, people have news apps in their phones to access to the worldwide news anytime and anywhere in any corner. Same is the case with farmwomen, $18 \%$ of the farm women are using news apps in their smart phones. Though this score is less but the progress is predicted.

\section{CONCLUSION}

it was found that vno women considered Media as their help in agricultural work. There is although, supply of newspapers in every households but farmwomen read them less. Radio is there but female listeners are less. Moreover, there is trend of using social media but only for leisure and entertainment purposes. Books and Magazines were not preferred at all. Whereas, Newspapers were welcomed but ultimately, Television was the most used and preferred type of Media. So, Punjabi newspaper Ajit (58\%) was widely acceptable and preferred newspaper for reading. Although, there was a supply of newspapers in every households but very less farmwomen reads newspapers (only 9\%). Radio is there but female listeners are just less than one third (30\%). Use of social media (51\%) is there but only for leisure and entertainment purposes. About half of the usage was of Whatsapp. Very few farmwomen read books $(4 \%)$ while Magazines were not preferred at all. Television was the most used and preferred type of Media (90\%). About one in 10 farmwomen $(9 \%)$ were specifically reading and watching agricultural coverage in different media.

\section{REFERENCES}

1. Amankwah A S (2010) A Review of Newspaper Reading Habits of Residents of the Adenta SSNIT Flats. Available at SSRN: http://ssrn.com/abstract $=1655740$ or doi: $10.2139 /$ ssrn. 1655740

2. Anonymous (1998) Survey on agricultural Internet use [Online] Available http://www.aic.ucdavis

3. Anonymous (2000) Who uses the internet in India. [Online]
Available http:// www.bangalorenetcom

4. Anonymous (2002) Selected case studies [Online] Available http://www. apdip.net/projects/ india.asp

5. Anonymous (2004) Internet. [Online] Available http://www.wmo.ch/web/www/WDM/ Guides/Internet-glossary.htm

6. Anonymous (2016) Future of Digital Content Consumption in
India $\mathrm{Pp}$
4-16 (Online
Available)

http://www.ey.com/Publication/vwLUAssets/ey-future-of-digitaljanuary-2016/\$FILE/ey-future-of-digital-january-2016.pdf

7. Anson R H (1973). The impact of social-psychological variables on farmer adoption behavior. Online availabe http://lib.dr.iastate.edu/cgi/viewcontent.cgi?article=7184\&context=rtd

8. Becker A E (2004) Television, Disordered Eating, And Young Women In Fiji: Negotiating Body Image And Identity During Rapid Social Change, Culture, Medicine and Psychiatry 28: 533-559, 2004. Department of Psychiatry, Massachusetts General Hospital Boston, MA, USA.

9. Beniwal A K (2015) A Comparative Study of Agricultural Coverage in Daily Newspapers, (Aug 2014). Online available http://eprints.unimysore.ac.in/14546/1/Content\%20Analysis\%20of\%20Agricultural\%2 0News-.pdf

10. Bhavya K (2009) Newspaper reading behaviour of farmers Mysore Journal of Agricultural Sciences 43(4): 779-782.

11. Dhanukar H S, Gaikwad S P and Tambe B N (2011) Reading habits of the farmers Agriculture Update 6 (3/4):87-89.

12. Farmers W and Schemes G (n.d.). Farm Women Friendly Hand Book.

13. Fawole O P and Tijani S A (2013) Awareness and Participation of Farmers in Extension Activities of Agricultural Media Resources and Extension Centre in Ogun State, 12(1), 41-51.

14. For C (2015) Women in Agriculture Survey, 12. Retrieved from http://www.fb.org/tmp/ uploads/2015WomensSurvev/Renort.pdf introduction. (n.d.).

15. Hassan M S, Sulaiman M Y, Hayrol A M S, Mohd S . ... man A S, Asnarulkhadi A S and Siti A R (2011) Receiving the agriculture information through mass media and interpersonal sources among the rural community American Journal of Agricultural and Biologica Sciences 6(3): 451-61.

16. Hiremath U S and Balasubramanya A S (2009) Impact of TV watchinghabitsofruralwomenin Dharwad Green Farming 2(6): 40810 .

17. Kakade $\mathrm{O}$ and Kolar T (n.d.) Media Habits Among Women Organic Farmers In Karnataka, 2(8): 5-10.

18. [18] Lad A S and Deshmukh P R (2014) Utility Perception of Mass Media by Farm Women, 10: 76-79.

19. Lekshmi P S S, Chandrakandan K and Balasubramani N (2015) Mass media utilization behaviour of farm women. Agricultural Science Digest - A Research Journal, 35(1): 51. https://doi.org/10.5958/09760547.2015 .00010 .5

20. Malagar G (2007) Radio Listening and Televiewing Behaviour of Rural Women, Department of Extension and Communication Management College of Rural Home Science, Dharwad University of Agricultural Sciences, Dharwad - 580005 .

21. Nandi K (2011) Commentary Global Media Journal - Indian Edition/Summer Issue/June 2011. Global Media Journal, (June), 116.

22. O, O B and P O (2013) Preliminary Assessment of Newspaper Coverage of Agricultural News in Delta State: A Case Study of the Pointer Newspaper in Delta State, Asaba, Nigeria. Sustainable Agriculture Research, 2(3): 101-6. https://doi.org/10.5539/ sar.v2n3p101

23. Of A, Visible B, Progression I T S, Composite O N A and Vessel O P (n.d.) Final thesis.

24. Oslo (2013) Women in agriculture: gender equality is still a challenge. Online available http://yara.com/media/news_archive/women_in_agriculture.aspx("sea rch@ agris. fao.org," n.d.)

25. Rora B (n.d.) Blocks - Villages - Ludhiana Pakhowal, 1-2.

26. Sances A and D P (n.d.) Source of. In Practice.

27. Sanjeev K, Manibhushan T and Archana R (2014) Trichoderma: Mass production, formulation, quality control, delivery and its scope in commercialization in India for themanagement of plant diseases. African Journal of Agricultural Research, 9(53): 3838-52. https://doi.org/10.5897/AJAR2014.

28. Shamsodani A and Shojaee S (2015) Assessing the factors affecting lifestyle of rural women in Iran: a case study in Fahimiyan villageMamasani area. Journal of Biodiversity and Environmental Sciences (JBES) 6(1): 670-75

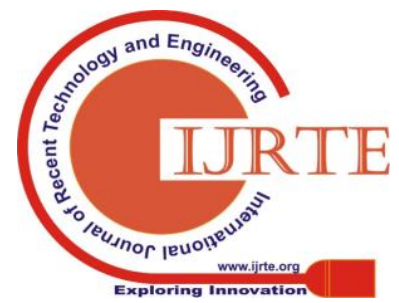


29. Singh A K (2011) Coverage of Development News in Print Media (A content analysis) Half Yearly Coverage of Developmen t News in Print Media (A content

analysis) Coverage of Development News in Print Media (A content analysis), 9180: 1-7.

30. Singh K G and Arya R (2012) A study of newspaper readership patterns among urban population of Punjab. Int J Mang IT \& Engg2: 58-74.

31. Skejby D (2001) Use of Internet in agriculture [Online] Available http://www.dina.kul.dk

32. Souza A, Kelleher A, Otr L, Cooper R, Cooper R A, Iezzoni L I and Collin

(2010) Review of Literature. Multiple Sclerosis https://doi.org/10.1682/JRRD. 2009.07.0096

33. The Power of Social Media in Agriculture: A Guide to Social Media Success. (n.d.).Thesis / Dissertation Postgraduate Students. (n.d.).

34. Wolswinkel H (2008) New Paper reading: the explaining factors of newspaper reading behavior of young adults M.Sc Thesis submitted toUniversity of Twente

35. Youngs G (2004) Women and Media. Women and Media: International Perspectives, 185-208. https://doi.org/10.1002/9780470776421

36. Zia A and Khan A (2012) Media Coverage for Development of Agriculture Sector: an Analytical Study of Television, 50(4): 555-64. 